\title{
Candida Interactions with the Oral Bacterial Microbiota
}

\author{
Daniel Montelongo-Jauregui and Jose L. Lopez-Ribot*iD \\ Department of Biology, South Texas Center for Emerging Infections Diseases, The University of Texas at \\ San Antonio, San Antonio, TX 78249, USA; daniel.montelongo@utsa.edu \\ * Correspondence: jose.lopezribot@utsa.edu; Tel.: +1-210-458-7022
}

Received: 11 October 2018; Accepted: 2 November 2018; Published: 3 November 2018

\begin{abstract}
The human oral cavity is normally colonized by a wide range of microorganisms, including bacteria, fungi, Archaea, viruses, and protozoa. Within the different oral microenvironments these organisms are often found as part of highly organized microbial communities termed biofilms, which display consortial behavior. Formation and maintenance of these biofilms are highly dependent on the direct interactions between the different members of the microbiota, as well as on the released factors that influence the surrounding microbial populations. These complex biofilm dynamics influence oral health and disease. In the latest years there has been an increased recognition of the important role that interkingdom interactions, in particular those between fungi and bacteria, play within the oral cavity. Candida spp., and in particular C. albicans, are among the most important fungi colonizing the oral cavity of humans and have been found to participate in these complex microbial oral biofilms. C. albicans has been reported to interact with individual members of the oral bacterial microbiota, leading to either synergistic or antagonistic relationships. In this review we describe some of the better characterized interactions between Candida spp. and oral bacteria.
\end{abstract}

Keywords: oral microbiota; Candida albicans; biofilms; interkingdom interactions

\section{Introduction}

Contemporary microbiome studies indicate that that over 700 species of microorganisms colonize the human oral cavity (http:/ / www.homd.org/). Given what an astoundingly microbe-rich niche the oral cavity is, the study of such a complex collection of microorganisms is very challenging. Among the great diversity of microorganisms found as residential microbiota, both in health and disease, there are representatives of the three domains of life: Archaea [1-3], Bacteria [1,2], and Eukarya [3,4]. Presence of microorganisms varies among individuals, reflecting differences in diet, sampling times of day, health status, and geographical locations, and also varies according to the microenvironment within the oral cavity under consideration (i.e., teeth, saliva, tongue, gingiva, and other epithelial surfaces of the oral mucosae) $[5,6]$. It is widely accepted that most microorganisms are found within multispecies biofilms, complex microbial communities with cooperative behavior covering the different surfaces within the oral cavity. Fortunately, with the emergence of newer technologies such as high throughput sequencing, a more thorough analysis can be performed to identify the many microorganisms present at a particular site. In this regard, efforts have been made to characterize what would be considered a healthy oral microbiota compared to that commonly associated with disease [7-9]. In healthy individuals, the $\mathrm{pH}$ of saliva is kept relatively neutral, which permits the growth of many microorganisms at a physiological temperature [10]. Early colonizers, predominantly streptococci and Actinomyces spp., bind to oral tissues via nonspecific interactions with charged surfaces in the host that are bathed with saliva, as well as with proteins and glycoproteins such as mucin in the same saliva, which, along with other metabolites (pellicle formation), promote adherence of the early colonizers, which in turn allows 
co-adherence of secondary colonizers [11-13]. Furthermore, saliva contains secretory IgA (s-IgA) which can inhibit bacterial attachment to dental surfaces and oral tissues [14]; for example caries-free patients tend to have higher concentration of s-IgA [15]. To overcome s-IgA and adhere to dental tissues, the early colonizer Streptococcus sanguinis is capable of producing IgA proteases [16], depleting s-IgA and permitting its adherence to host tissues in the oral cavity [17]. Also, early colonizers express a number of adhesins in their cell surface that are important for specific and nonspecific adherence to dental surfaces and other microorganisms. In this manner, antigen I/II (AgI/II) family polypeptides in oral streptococci $[18,19]$ have been described to mediate adhesion to oral tissues, as well as to other bacteria and fungi including A. naueslundii [20], P. gingivalis [21], and C. albicans [22].

Of increasing interest are interkingdom interactions within the oral microbiota, such as those established between fungi and bacteria $[3,23,24]$. Particularly intriguing are those interactions that lead to an increased pathogenicity of either microorganism involved $[25,26]$. The opportunistic pathogen Candida albicans is the most frequent fungus isolated during oral infections, and a number of studies have shown that different oral bacteria adhere to C. albicans in oral biofilms and can modulate its pathogenicity $[27,28]$. Moreover, these interactions are described to be multidirectional because the presence of C. albicans or other Candida spp. can also influence the behavior of the bacterial microbiota [29]. Therefore, one has to consider the sum of interactions between all the microorganisms involved, which ultimately gives rise to a tremendous degree of complexity associated with these multispecies oral biofilms. In this review we elaborate on some of the best characterized interactions between individual oral bacteria and Candida spp., with special emphasis on C. albicans, the fungal species most commonly isolated from the oral cavity.

\section{C. albicans Interactions with Oral Streptococci}

\subsection{Mutans Group Streptococci}

\section{Streptococcus mutans}

Streptococcus mutans, the etiological agent of early childhood caries (ECC) [30], has been described to intimately communicate with C. albicans in a complex bidirectional interaction [25]. It has been thoroughly described that carbohydrate consumption, in particular sucrose is closely linked to the development of tooth decay [31]. In fact, long-term excessive carbohydrate uptake can lead to a cariogenic microbiota, lowering $\mathrm{pH}$, and increasing the presence of mutans streptococci such as S. mutans, while the presence of noncariogenic streptococci under these conditions is diminished [32,33]. Aside from sucrose, S. mutans feeds off various other carbohydrate sources such a glucose, fructose, mannose, and other fermentable sugars via the phosphotransferase system (PTS) that lead to production of exopolymeric substance (EPS) in the biofilm matrix and acid, which is common in the formation of dental caries [34,35]. A well-recognized mechanism for the breakdown of sucrose is through the secretion of the exoenzymes known as glucosyltranferases (Gtfs), which catalyze the transfer of glucosyl units formed following the cleavage of sucrose to a growing $\alpha$-glucose chain as glucan polymers assemble, also producing fructose in the process [36]. It has been demonstrated in vitro that high levels of sucrose can lead to increased interactions between S. mutans and C. albicans, resulting in dramatically enhanced microbial burden and production of biofilm matrix, which could potentially have important clinical repercussions in the production of severe childhood caries [37-39]. In particular as it relates to interactions with C. albicans, GtfB helps the fungus by producing carbohydrate that can then be metabolized by C. albicans [40]. Interestingly, GtfB can also bind directly to the surface of $C$. albicans, allowing it to adhere to dental surfaces and leading to the formation of mixed biofilms [41]; additionally, S. mutans GtfB has been shown to upregulate the expression of HWP1, ALS1, and ALS3 genes encoding important adhesins in C. albicans [42]. Furthermore, an RNA-Seq study from co-cultures showed that the presence of $C$. albicans enhances sugar metabolism pathways of $S$ mutans [43]. Using C. albicans mutants in vitro, Hwang et al. demonstrated that mannans on the fungal cell wall have an important role in the direct binding with GtfB, as they observed reduced 
interaction with C. albicans mutants deficient in O-mannan and $\mathrm{N}$-mannan outer chain, $\Delta p m t 4$ and $\Delta o c h 1$, respectively, which resulted in poor mixed biofilm formation [44]. Confirmation of these observations were performed in an in vivo rodent model of dental caries, showing that the C. albicans $\Delta o c h 1$ mutant was deficient in adhesion to tooth surfaces of rats even in the presence of $S$. mutans [44]. Furthermore, adherence of GtfB and production of EPS has been reported to increase C. albicans resistance to fluconazole treatment, and disruption of EPS by povidone iodine in combination with fluconazole rendered the antifungal treatment more effective [45]. Moreover, the addition of the bacterium Lactobacillus salivarius in multispecies biofilms can inhibit in vitro biofilm formation of both S. mutans and C. albicans [46].

Confounding matters for the classification of this relationship as always synergistic are secreted factors detected on spent media of $S$. mutans cultures that negatively affect growth and pathogenetic characteristics of $C$. albicans. Quorum sensing molecules, such as the competence-stimulating peptide (CSP) [47], trans-2-decenoic acid [48], and mutanobactin A [49], have been reported to inhibit filamentation and induce $C$. albicans yeast formation. Interestingly, presence of $C$. albicans can influence the expression of those factors in S. mutans as Sztajer et al. were able to detect stimulation of quorum-sensing using spent media from dual-species biofilms [50]. The authors reported the spent media from a co-culture to induce expression of quorum sensing regulon, inducing CSP and XIP (alternative sigma factor sigX-inducing peptide) important for induction competence in S. mutans, as well as production of mutacins and fratricins [50]. Additionally, the fungal quorum sensor farnesol was also shown to enhance S. mutans biofilm formation, microcolony development, and GtfB activity at low concentrations [51]; while proven to have antibacterial properties at high concentrations [52].

Furthermore, in a recent publication, a member of the AgI/II family polypeptides, which was first identified in S. mutans [53], SpaP, has been found to be important direct interaction with C. albicans in vitro, and to facilitate colonization of both microorganisms in a D. melanogaster in vivo model [54].

\subsection{Mitis Group Streptococci}

Many members of the mitis group of streptococci have been identified to interact with C. albicans $[55,56]$. This group consists mostly of early colonizers of the oral microbiota, and given their promiscuity at binding different surfaces and microorganisms, they are considered initial settlers of dental plaque [57]. The mitis group comprises 13 species of streptococci including four species, namely S. gordonii, S. mitis, S. oralis, and S. sanguinis, for which existing evidence indicates their ability to interact directly with C. albicans [55]. Here we will list some of the most relevant interactions between C. albicans and the mitis group members.

\subsubsection{Streptococcus gordonii}

Existing evidence points out to the various ways in which these two microorganisms, Streptococcus gordonii and C. albicans, interact with one another (Figure 1), with most information coming from the streptococcal side. These interactions have reported to be mostly synergistic [28,58-60], and have revealed to be through both direct physical contact and the release of diffusible factors [58]. Various in vitro models have been designed to study their interactions including biofilms grown on microtiter plates with or without presence of an artificial salivary pellicle [58,59], titanium implant material [60], and biofilms grown on mucosal tissue analogs [28]. Streptococcal adhesins CshA as well as SspA and SspB (belonging to the AgI/II family polypeptides) have been identified to be important for the direct binding to fungal cells; in particular SspB was shown to directly bind to hyphal-specific adhesins Als3, Eap1, and Hwp1 [22,58,61,62]. The same group tested the regions of Als3 responsible for the binding to S. gordonii, concluding that deletion of amino acids in the N-terminal region of the protein significantly reduced their interaction [61]. It was also demonstrated that $C$. albicans mutant strains defective in $O$-mannosylation, such as $\Delta m n t 1$ and $\Delta m n t 2$ mutants, do not show a strong direct association with S. gordonii [63], with follow-up studies demonstrating a role for secreted aspartyl protease 9 (Sap9) 
during the interaction of both microorganisms by modulating cell surface hydrophobicity and the expression of other surface adhesins, most notably Eap1 [64].

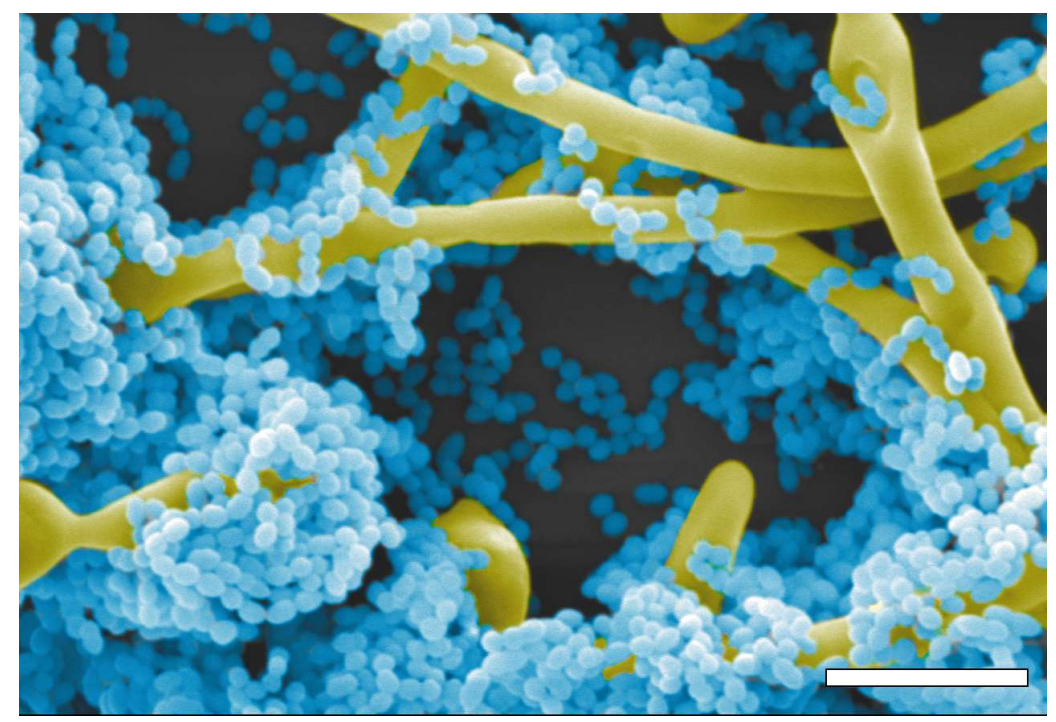

Figure 1. Pseudo-colored image of a scanning electron micrograph of mixed biofilms of C. albicans SC5314 (yellow) and S. gordonii DL1.1 (blue). Scale bar is $5 \mu \mathrm{m}$.

With respect to the communication of these microorganisms via released factors, Bamford et al. tested this interaction using an S. gordonii $\triangle l u x S$ mutant, which is a gene important for the production of autoinducer 2 (AI-2), a quorum sensing factor released and recognized by a great number of bacterial species that permit their cross-talk $[58,65,66]$. The authors observed reduced biofilm biomass in the presence of this mutant as well as less hyphal formation by C. albicans. Interestingly, they also observed that the presence of $S$. gordonii inhibited the effect of addition of exogenous farnesol to C. albicans, showing that the likely mechanism by which S. gordonii can induce C. albicans filamentation is by blocking the effect of farnesol repression at later stages of biofilm formation [58]. Ricker et al. observed that $S$. gordonii expression of glucosyltransferase G (GtfG) also contributes to coaggregation with C. albicans [67] in a very similar fashion to what was described in the case of $S$. mutans $[41,44,68]$. Finally, the growth of both microorganisms in the form of mixed biofilms also appears to be relevant in their increased resistance to antimicrobial treatment $[59,60]$.

Similarly to what is observed with S. mutans, CSP produced by S. gordonii can modulate mixed biofilm formation, as it was demonstrated that the S. gordonii comCDE (competence) operon influences the formation of mixed biofilms with C. albicans, mostly by modulating the production of eDNA and the incorporation of fungal cells within mixed biofilms [69].

\subsubsection{Streptococcus oralis}

Similar to C. albicans, S. oralis is mostly considered an oral commensal; however, it is also an opportunistic pathogen in immunocompromised individuals like cancer and cystic fibrosis patients [70-73]. Together, these two microorganisms were shown to form stronger biofilms when mixed compared to their respective single-species counterparts [28]. Diaz et al. observed strong biofilm formation and increased invasion in a mucosal tissue analog compared to the individual species, suggesting that they synergize during infection [28]. This synergism was corroborated using an in vivo murine model where both microorganisms were given orally to immunosuppressed mice. Results indicated higher streptococcal burden and colonization in the presence of $C$. albicans, demonstrating that $S$. oralis benefits from the presence of $C$. albicans in vivo [74]. The authors also observed an exacerbated inflammatory response during mixed infection that was dependent of TLR2 signaling [74]. The same group demonstrated that biofilm formation with these mixed microorganisms 
is higher in moist compared to dry environments, and that high nutrient availability increases tissue invasiveness [75]. C. albicans pseudohyphal mutants displayed decreased interaction with S. oralis compared to C. albicans cells that can produce true hyphae [75].

In recent publications, $\mathrm{Xu}$ et al. showed that, both in vitro and in vivo, S. oralis and C. albicans co-infection leads to an increased invasion of mucosal tissues due in part to the release of $\mu$-calpain, which degrades E-cadherin junctions of epithelial cells, permitting access to both fungal and bacterial cells [76]. S. oralis is also capable of inducing C. albicans filamentation through the master regulator EFG1 [70]. Finally, a new in vivo model was recently developed for the study of these interactions using a clinically relevant murine model that mimics chemotherapy-induced mucositis after treatment with 5-fluorouracil [71,72].

\subsubsection{Streptococcus sanguinis, Streptococcus parasanguinis, and Streptococcus mitis}

There have been reports that S. mitis, S. sanguinis, and S. parasinguinis are able to interact with C. albicans $[28,56,73,77-79]$. S. sanguinis has been reported to synergize with C. albicans during biofilm formation [28]. Previously, S. sanguinis had been recognized to produce a bacteriocin that has antibacterial properties [80]. Ma et al. tested the effect a bacteriocin against oral pathogens such as P. gingivalis and Prevotella intermedia and fungal species C. albicans and C. tropicalis [77]. The authors observed that intracellular proteins from an extract produced by $S$. sanguinis in culture medium displays antibacterial activity against as $P$. gingivalis and $P$. intermedia, as well as inhibitory effects on growth and filamentation of both Candida spp. [77], thereby reflecting the important role that S. sanguinis plays in the oral microbiota. Despite of this, the sum of all stimuli in multispecies biofilms using S. sanguinis and other oral bacteria promoted virulence of C. albicans in acrylic surfaces [78] and titanium [79]. Novel treatments against these resilient mixed biofilms have been described, including some promising results using photodynamic inactivation [81].

\subsection{Salivarius Group Streptococci}

\section{Streptococcus salivarius}

The S. salivarius probiotic strain K12 inhibits adherence and filamentation of C. albicans, and in a murine model of infection candidiasis protected mice from severe candidiasis [82]. The effects were not fungicidal and may be different than those displayed as a probiotic against other bacterial species, which are mostly mediated by the antimicrobial activity of bacteriocin-like inhibitory substances.

\section{C. albicans Interactions with Other Oral Bacteria}

\subsection{Porphyromonas gingivalis}

C. albicans has been reported to interact with the pathogenic periodontal bacterium Porphyromonas gingivalis, a major etiological agent of chronic periodontitis [83]. Interestingly, similar to what is observed in the mitis group of streptococci, hyphal-specific adhesin Als3 on the fungal surface is considered to be important for the interaction with P. gingivalis [84], and pretreatment of gingival epithelial cells and fibroblasts with C. albicans increased P. gingivalis invasion [85]. Interestingly, S. gordonii can bind directly to and communicate with P. gingivalis via secreted factors, exacerbating its pathogenicity leading to periodontal disease [86-88]. In addition, as previously discussed, S. gordonii can be considered an aide of $C$. albicans attachment and filamentation in oral tissues. Thus, this three-way Candida-Streptococcal-Porphyromonas interaction represents an intriguing example of the complexity associated with oral microbiota studies. Moreover, Haverman et al. used an in vitro assay that demonstrates that $P$. gingivalis can delay oral epithelium cell migration when interacting with other Candida spp. such as C. kefyr and C. glabrata [89]. 


\subsection{Actinomyces spp.}

Along with various species of streptococci, Actinomyces spp. are among the first colonizers of oral surfaces and tissues [90-92]. Various Actinomyces spp., including A. viscosus [73,78,93], A. naeslundii [93-96], A. odontolyticus [78], and A. oris [97,98], have been described to co-aggregate with $C$. albicans. Evidence has shown that this interaction is not necessarily contact-dependent, as some metabolites produced by $A$. naeslundii and $A$. viscosus inhibit $C$. albicans growth at high concentrations and boost its growth at lower concentrations [93]. A second report showed that A. viscosus, A. naeslundii, and A. odontolyticus cell suspensions, supernatants, and bacterial lysates were able to inhibit growth of C. albicans [99]. Additionally, C. albicans adhesion to buccal epithelial cells and hyphal formation was reduced, while production of phospholipase $C$ was increased, after incubation with supernatants from Actinomyces spp. [99]. It has also been reported that $C$. albicans coaggregation with $A$. viscosus, $A$. naeslundii, and A. odontolyticus appears to depend on the fungal strain [95] and medium of growth [96]. There are previous reports that Actinomyces spp. can also co-aggregate with oral streptococci [91,92] in particular with S. oralis [91], which in turn suggests that C. albicans could form a triad with both early colonizers. Interestingly, publications from Cavalcanti et al. highlight the potential of $A$. oris to incorporate into mixed biofilms with $S$. oralis and C. albicans on denture material [97] and salivary pellicles [98]. In biofilms grown on acrylic resin, the authors observed synergism and collaboration in the triad mixed biofilms, despite the fact that in dual species biofilms the biovolume of $C$. albicans only discretely augmented in the presence of $A$. oris [97]. Also, they demonstrated that mutants of $A$. oris lacking type 1 and 2 fimbriae were not able to bind to $S$. oralis but were still able to adhere to C. albicans in the mixed biofilms [98].

\subsection{Fusobacterium nucleatum}

The common oral commensal Fusobacterium spp. have also proved to be opportunistic pathogens associated with a very diverse range of diseases, from oral and gastrointestinal infections to adverse pregnancy outcomes [100]. Interestingly, many Fusobacterium species have been demonstrated to adhere to C. albicans [101] and C. dubliniensis [102]. Work from Wu et al. revealed that coaggregation of C. albicans and F. nucleatum is partly the result of expression of C. albicans FLO9 encoding an adhesin-like cell wall mannan and F. nucleatum radD encoding an arginine-inhibitable adhesin; although the authors could not conclude if these two factors interact directly with one another in their in vitro assay [103]. Moreover, the interaction can be inhibited by the addition of mannose or arginine to wild-type strains [103]. Interestingly, F. nucleatum expression of radD along with aid1 has also been described to be important in the coaggregation of oral streptococci and both adhesins can be inhibited by the addition of arginine [104,105]. In a follow-up publication, the same group concluded that both microorganisms attenuate virulence of one-another mutually in a contact-dependent manner: the macrophage-killing ability of C. albicans was reduced because $F$. nucleatum inhibits filamentation, while the yeast also repressed F. nucleatum-induced macrophage responses [106]. The authors concluded that this mutualistic attenuation of virulence may benefit both microorganisms by promoting long-term commensalism within the oral cavity.

\subsection{Rothia dentocariosa}

Considered an emerging opportunistic bacterium, Rothia dentocariosa has been reported to be commonly isolated together with $C$. albicans from failed silicone voice prostheses in patients that underwent a laryngectomy [107] and patients that required frequent replacement of such prostheses [26,108]. Millsap et al. tested used various bacteria in combination with Candida spp. on silicone rubber surface for their ability to enhance fungal colonization, concluding that $R$. dentocariosa, S. aureus, and S. mitis aided colonization of C. albicans and C. tropicalis [109]; the same species also worsened air flow resistance in these devices [110]. However, despite this increase in adhesion, the same group also reported that the bacterium reduced filamentation and overall biofilm formation 
by C. albicans [108]. Uppuluri et al. tested the interaction of $R$. dentocariosa with C. albicans in vitro using suspension cultures and growing mixed biofilms on silicone rubber [111]. The authors observed delayed planktonic growth and decreased filamentation in C. albicans biofilms [111]. Furthermore, biomass in mixed-biofilms was reported to be 2-fold lower compared to monospecies C. albicans biofilms [111]. These observations were corroborated by determining global transcriptional profiles of mixed biofilms, in which C. albicans genes involved in regulation of filamentation as well as hyphal-specific genes were downregulated as compared to expression levels detected in monospecies C. albicans biofilms [111]. Interestingly despite of the transcriptional data, the group observed that the hyphal-specific adhesin Als3 was important for the interaction of both microorganisms [111].

\subsection{Aggregatibacter actinomycetemcomitans}

An oral commensal and opportunistic pathogen [112], Aggregatibacter actinomycetemcomitans was recently included in the list of oral bacteria that can interact with C. albicans [113]. Despite being the only report on this interaction to date, Bacthiar et al. observed the effect by a common factor used by many oral bacteria, AutoInducer-2 (A1-2) [113]. Recently, AI-2 was described to be required for biofilm formation of A. actinomycetemcomitans [114]. A. actinomycetemcomitans is able to inhibit biofilm formation by $C$. albicans in co-cultures but this effect is rescued using a $\triangle l u x S$ mutant strain that cannot produce AI-2 [113]. Additionally, spent medium from wild-type A. actinomycetemcomitans was also able to inhibit biofilm formation and disrupt $C$. albicans preformed biofilms [113]. Intriguingly, AI-2 from A. actinomycetemcomitans inhibits $C$. albicans hyphal formation, while the same factor produced by S. gordonii [58] has the opposite effect, suggesting differences between the factors released by each bacterial species.

\subsection{Staphylococcus aureus}

An opportunistic pathogen and one of leading causes of nosocomial infections, S. aureus is also commonly isolated from the oral cavity of healthy individuals $[115,116]$ as well as from patients with oral infections that are also commonly associated with the presence of $C$. albicans, such as denture stomatitis [117,118] and angular cheilitis [119-122]. S. aureus is thought to benefit from the presence of $C$. albicans. Using in vitro models, Peters et al. described the S. aureus ability adhere to Als3 in hyphae [123]. Using a co-colonization oral murine model Schlecht et al. observed a synergistic infection by both C. albicans and S. aureus. However, if mice were inoculated with an $\Delta a l s 3$ C. albicans mutant strain, despite the detection of colonization in tongues of the animals, S. aureus could not get into the bloodstream and cause disseminated infection [124]. Recently, a study showed increased production and an important role for eDNA in these mixed biofilms, with the authors concluding that eDNA supported S. aureus adherence in the dual-species biofilms [125]. It was also demonstrated that the presence of $C$. albicans or its secreted cell wall polysaccharide material in mixed biofilms significantly enhanced the tolerance of $S$. aureus to antibacterial antibiotics [126].

\subsection{Enterococcus faecalis}

There is growing evidence for the coexistence between enterococci and C. albicans, including within the oral cavity [127-129]. For example, E. faecalis and C. albicans were co-isolated in approximately $10 \%$ of root canal and periapical infections, and in approximately $40 \%$ of oral mucosal lesions [129]. Another retrospective study found E. faecalis among the bacterial microbiota most often accompanying Candida spp. in oral samples [127]. Of note, a recent report indicates that E. faecalis can inhibit C. albicans filamentation, biofilm formation, and overall virulence [130]. Further experiments demonstrated that a secreted bacterial compound was responsible for the inhibition of hyphal growth in dual-species biofilms, and that this inhibition was partially dependent on the Fsr quorum-sensing system, a major regulator of virulence in this opportunistic pathogenic bacterium [131]. 


\section{Non-albicans Candida Species in the Oral Microbiome}

There is an increased recognition of the role that non-albicans Candida species (NACS) play in the oral cavity both as commensals and etiological agents of infection, including some of the interactions among different Candida species [132-139]. Unfortunately, very little is known about NACS interactions with oral bacteria, as most focus has been placed on Candida albicans. For example C. dubliniensis has been described to interact with Fusobacterium nucleatum [102], and a clinical isolate of $C$. tropicalis was reported to be capable of coaggregating with different oral bacteria including F. nucleatum, A. viscosus, oral streptococci, and L. amylovorous [140]. Clearly, more work is needed in order to elucidate the NACS interactions with oral bacteria both in health and disease.

Author Contributions: Both authors, D.M.-J. and J.L.L.-R., reviewed the pertinent literature on this topic and contributed to the writing of this review.

Funding: Biofilm-related work in the laboratory is supported by grants numbered R01DE023510 and R01AI119554 from the National Institute of Dental and Craniofacial Research and the National Institute of Allergy and Infectious Diseases, respectively to J.L.L.-R.. Additional support was provided by the Margaret Batts Tobin Foundation, San Antonio, TX.

Acknowledgments: The authors are indebted to all researchers working on this expanding field and apologize for any unintended omissions of work not included in this review.

Conflicts of Interest: The authors declare no conflicts of interest. The funders had no role in the design of the study; in the collection, analyses, or interpretation of data; in the writing of the manuscript, and in the decision to publish the results.

\section{References}

1. Seminario, A.; Broukal, Z.; Ivancakova, R. Mutans streptococci and the development of dental plaque. Prague Med. Rep. 2005, 106, 349-358. [PubMed]

2. Avila, M.; Ojcius, D.M.; Yilmaz, O. The oral microbiota: Living with a permanent guest. DNA Cell Biol. 2009, 28, 405-411. [CrossRef] [PubMed]

3. Lof, M.; Janus, M.M.; Krom, B.P. Metabolic interactions between bacteria and fungi in commensal oral biofilms. J. Fungi 2017, 3, 40.

4. Krom, B.P.; Kidwai, S.; Ten Cate, J.M. Candida and other fungal species: Forgotten players of healthy oral microbiota. J. Dent. Res. 2014, 93, 445-451. [CrossRef] [PubMed]

5. Delgado-Silva, Y.; Vaz, C.; Carvalho-Pereira, J.; Carneiro, C.; Nogueira, E.; Correia, A.; Carreto, L.; Silva, S.; Faustino, A.; Pais, C.; et al. Participation of Candida albicans transcription factor RLM1 in cell wall biogenesis and virulence. PLoS ONE 2014, 9. [CrossRef] [PubMed]

6. Costalonga, M.; Herzberg, M.C. The oral microbiome and the immunobiology of periodontal disease and caries. Immunol. Lett. 2014, 162, 22-38. [CrossRef] [PubMed]

7. Hezel, M.P.; Weitzberg, E. The oral microbiome and nitric oxide homoeostasis. Oral Dis. 2015, $21,7-16$. [CrossRef] [PubMed]

8. Seneviratne, C.J.; Zhang, C.F.; Samaranayake, L.P. Dental plaque biofilm in oral health and disease. Chin. J. Dent. Res. 2011, 14, 87-94. [PubMed]

9. Human Microbiome Project Consortium. Structure, function and diversity of the healthy human microbiome. Nature 2012, 486, 207-214. [CrossRef] [PubMed]

10. Marsh, P.D. Are dental diseases examples of ecological catastrophes? Microbiology 2003, 149, $279-294$. [CrossRef] [PubMed]

11. Busscher, H.J.; van der Mei, H.C. Initial microbial adhesion events: Mechanisms and implications. In Community Structure and Co-Operation in Biofilms; Allison, D.G., Gilbert, P., Lappin-Scott, H.M., Wilson, M., Eds.; Cambridge University Press: Cambridge, UK, 2000; Volume 59, pp. 25-36.

12. Busscher, H.J.; van der Mei, H.C. Physico-chemical interactions in initial microbial adhesion and relevance for biofilm formation. Adv. Dent. Res. 1997, 11, 24-32. [CrossRef] [PubMed]

13. Yao, Y.; Berg, E.A.; Costello, C.E.; Troxler, R.F.; Oppenheim, F.G. Identification of protein components in human acquired enamel pellicle and whole saliva using novel proteomics approaches. J. Biol. Chem. 2003, 278, 5300-5308. [CrossRef] [PubMed] 
14. Williams, R.C.; Gibbons, R.J. Inhibition of bacterial adherence by secretory immunoglobulin A: A mechanism of antigen disposal. Science 1972, 177, 697-699. [CrossRef] [PubMed]

15. Mira, A.; Artacho, A.; Camelo-Castillo, A.; Garcia-Esteban, S.; Simon-Soro, A. Salivary immune and metabolic marker analysis (simma): A diagnostic test to predict caries risk. Diagnostics 2017, 7, 38. [CrossRef] [PubMed]

16. Genco, R.J.; Plaut, A.G.; Moellering, R.C., Jr. Evaluation of human oral organisms and pathogenic streptococcus for production of iga protease. J. Infect. Dis. 1975, 131, S17-S21. [CrossRef] [PubMed]

17. Li, J.; Helmerhorst, E.J.; Leone, C.W.; Troxler, R.F.; Yaskell, T.; Haffajee, A.D.; Socransky, S.S.; Oppenheim, F.G. Identification of early microbial colonizers in human dental biofilm. J. Appl. Microbiol. 2004, 97, 1311-1318. [CrossRef] [PubMed]

18. Jenkinson, H.F.; Demuth, D.R. Structure, function and immunogenicity of streptococcal antigen I/II polypeptides. Mol. Microbiol. 1997, 23, 183-190. [CrossRef] [PubMed]

19. Brady, L.J.; Maddocks, S.E.; Larson, M.R.; Forsgren, N.; Persson, K.; Deivanayagam, C.C.; Jenkinson, H.F. The changing faces of Streptococcus antigen I/II polypeptide family adhesins. Mol. Microbiol. 2010, 77, 276-286. [CrossRef] [PubMed]

20. Jakubovics, N.S.; Stromberg, N.; van Dolleweerd, C.J.; Kelly, C.G.; Jenkinson, H.F. Differential binding specificities of oral streptococcal antigen I/II family adhesins for human or bacterial ligands. Mol. Microbiol. 2005, 55, 1591-1605. [CrossRef] [PubMed]

21. Daep, C.A.; James, D.M.; Lamont, R.J.; Demuth, D.R. Structural characterization of peptide-mediated inhibition of Porphyromonas gingivalis biofilm formation. Infect. Immun. 2006, 74, 5756-5762. [CrossRef] [PubMed]

22. Silverman, R.J.; Nobbs, A.H.; Vickerman, M.M.; Barbour, M.E.; Jenkinson, H.F. Interaction of Candida albicans cell wall ALS3 protein with Streptococcus gordonii ssp adhesin promotes development of mixed-species communities. Infect. Immun. 2010, 78, 4644-4652. [CrossRef] [PubMed]

23. Shirtliff, M.E.; Peters, B.M.; Jabra-Rizk, M.A. Cross-kingdom interactions: Candida albicans and bacteria. FEMS Microbiol. Lett. 2009, 299, 1-8. [CrossRef] [PubMed]

24. Arvanitis, M.; Mylonakis, E. Fungal-bacterial interactions and their relevance in health. Cell Microbiol. 2015, 17, 1442-1446. [CrossRef] [PubMed]

25. Koo, H.; Bowen, W.H. Candida albicans and Streptococcus mutans: A potential synergistic alliance to cause virulent tooth decay in children. Future Microbiol. 2014, 9, 1295-1297. [CrossRef] [PubMed]

26. Elving, G.J.; van der Mei, H.C.; Busscher, H.J.; van Weissenbruch, R.; Albers, F.W. Comparison of the microbial composition of voice prosthesis biofilms from patients requiring frequent versus infrequent replacement. Ann. Otol. Rhinol. Laryngol. 2002, 111, 200-203. [CrossRef] [PubMed]

27. Radford, D.R.; Challacombe, S.J.; Walter, J.D. Denture plaque and adherence of Candida albicans to denture-base materials in vivo and in vitro. Crit. Rev. Oral Biol. Med. 1999, 10, 99-116. [CrossRef] [PubMed]

28. Diaz, P.I.; Xie, Z.; Sobue, T.; Thompson, A.; Biyikoglu, B.; Ricker, A.; Ikonomou, L.; Dongari-Bagtzoglou, A. Synergistic interaction between Candida albicans and commensal oral streptococci in a novel in vitro mucosal model. Infect. Immun. 2012, 80, 620-632. [CrossRef] [PubMed]

29. Cho, T.; Nagao, J.; Imayoshi, R.; Tanaka, Y. Importance of diversity in the oral microbiota including candida species revealed by high-throughput technologies. Int. J. Dent. 2014, 2014, 454391. [CrossRef] [PubMed]

30. Pidamale, R.; Sowmya, B.; Thomas, A.; Jose, T.; Madhusudan, K.K.; Prasad, G. Association between early childhood caries, Streptococcus mutans level and genetic sensitivity levels to the bitter taste of, 6-N propylthiouracil among the children below 71 months of age. Dent. Res. J. 2012, 9, 730-734.

31. Rugg-Gunn, A. Dental caries: Strategies to control this preventable disease. Acta Med. Acad. 2013, 42, 117-130. [CrossRef] [PubMed]

32. Dennis, D.A.; Gawronski, T.H.; Sudo, S.Z.; Harris, R.S.; Folke, L.E. Variations in microbial and biochemical components of four-day plaque during a four-week controlled diet period. J. Dent. Res. 1975, 54, 716-722. [CrossRef] [PubMed]

33. Staat, R.H.; Gawronski, T.H.; Cressey, D.E.; Harris, R.S.; Folke, L.E. Effects of dietary sucrose levels on the quantity and microbial composition of human dental plaque. J. Dent. Res. 1975, 54, 872-880. [CrossRef] [PubMed]

34. Bowen, W.H.; Burne, R.A.; Wu, H.; Koo, H. Oral biofilms: Pathogens, matrix, and polymicrobial interactions in microenvironments. Trends Microbiol. 2018, 26, 229-242. [CrossRef] [PubMed] 
35. Bowen, W.H.; Koo, H. Biology of Streptococcus mutans-derived glucosyltransferases: Role in extracellular matrix formation of cariogenic biofilms. Caries Res. 2011, 45, 69-86. [CrossRef] [PubMed]

36. Ajdic, D.; Chen, Z. A novel phosphotransferase system of Streptococcus mutans is responsible for transport of carbohydrates with alpha-1,3 linkage. Mol. Oral Microbiol. 2013, 28, 114-128. [CrossRef] [PubMed]

37. Branting, C.; Sund, M.L.; Linder, L.E. The influence of Streptococcus mutans on adhesion of Candida albicans to acrylic surfaces in vitro. Arch. Oral Biol. 1989, 34, 347-353. [CrossRef]

38. Pereira-Cenci, T.; Deng, D.M.; Kraneveld, E.A.; Manders, E.M.; Del Bel Cury, A.A.; Ten Cate, J.M.; Crielaard, W. The effect of Streptococcus mutans and Candida glabrata on Candida albicans biofilms formed on different surfaces. Arch. Oral Biol. 2008, 53, 755-764. [CrossRef] [PubMed]

39. Metwalli, K.H.; Khan, S.A.; Krom, B.P.; Jabra-Rizk, M.A. Streptococcus mutans, Candida albicans, and the human mouth: A sticky situation. PLoS Pathog 2013, 9. [CrossRef] [PubMed]

40. Falsetta, M.L.; Klein, M.I.; Colonne, P.M.; Scott-Anne, K.; Gregoire, S.; Pai, C.H.; Gonzalez-Begne, M.; Watson, G.; Krysan, D.J.; Bowen, W.H.; et al. Symbiotic relationship between Streptococcus mutans and Candida albicans synergizes virulence of plaque biofilms in vivo. Infect. Immun. 2014, 82, 1968-1981. [CrossRef] [PubMed]

41. Hwang, G.; Marsh, G.; Gao, L.; Waugh, R.; Koo, H. Binding force dynamics of Streptococcus mutans-glucosyltransferase B to Candida albicans. J. Dent. Res. 2015, 94, 1310-1317. [CrossRef] [PubMed]

42. Ellepola, K.; Liu, Y.; Cao, T.; Koo, H.; Seneviratne, C.J. Bacterial gtfb augments Candida albicans accumulation in cross-kingdom biofilms. J. Dent. Res. 2017, 96, 1129-1135. [CrossRef] [PubMed]

43. He, J.; Kim, D.; Zhou, X.; Ahn, S.J.; Burne, R.A.; Richards, V.P.; Koo, H. RNA-seq reveals enhanced sugar metabolism in Streptococcus mutans co-cultured with Candida albicans within mixed-species biofilms. Front. Microbiol. 2017, 8, 1036. [CrossRef] [PubMed]

44. Hwang, G.; Liu, Y.; Kim, D.; Li, Y.; Krysan, D.J.; Koo, H. Candida albicans mannans mediate Streptococcus mutans exoenzyme GTFB binding to modulate cross-kingdom biofilm development in vivo. PLoS Pathog 2017, 13. [CrossRef] [PubMed]

45. Kim, D.; Liu, Y.; Benhamou, R.I.; Sanchez, H.; Simon-Soro, A.; Li, Y.; Hwang, G.; Fridman, M.; Andes, D.R.; $\mathrm{Koo}, \mathrm{H}$. Bacterial-derived exopolysaccharides enhance antifungal drug tolerance in a cross-kingdom oral biofilm. ISME J. 2018, 12, 1427-1442. [CrossRef] [PubMed]

46. Krzysciak, W.; Koscielniak, D.; Papiez, M.; Vyhouskaya, P.; Zagorska-Swiezy, K.; Kolodziej, I.; Bystrowska, B.; Jurczak, A. Effect of a lactobacillus salivarius probiotic on a double-species Streptococcus mutans and Candida albicans caries biofilm. Nutrients 2017, 9, 1242. [CrossRef] [PubMed]

47. Pestova, E.V.; Havarstein, L.S.; Morrison, D.A. Regulation of competence for genetic transformation in Streptococcus pneumoniae by an auto-induced peptide pheromone and a two-component regulatory system. Mol. Microbiol. 1996, 21, 853-862. [CrossRef] [PubMed]

48. Vilchez, R.; Lemme, A.; Ballhausen, B.; Thiel, V.; Schulz, S.; Jansen, R.; Sztajer, H.; Wagner-Dobler, I. Streptococcus mutans inhibits Candida albicans hyphal formation by the fatty acid signaling molecule trans-2-decenoic acid (SDSF). Chembiochem 2010, 11, 1552-1562. [CrossRef] [PubMed]

49. Joyner, P.M.; Liu, J.; Zhang, Z.; Merritt, J.; Qi, F.; Cichewicz, R.H. Mutanobactin a from the human oral pathogen Streptococcus mutans is a cross-kingdom regulator of the yeast-mycelium transition. Org. Biomol. Chem. 2010, 8, 5486-5489. [CrossRef] [PubMed]

50. Sztajer, H.; Szafranski, S.P.; Tomasch, J.; Reck, M.; Nimtz, M.; Rohde, M.; Wagner-Dobler, I. Cross-feeding and interkingdom communication in dual-species biofilms of Streptococcus mutans and Candida albicans. ISME J. 2014, 8, 2256-2271. [CrossRef] [PubMed]

51. Kim, D.; Sengupta, A.; Niepa, T.H.; Lee, B.H.; Weljie, A.; Freitas-Blanco, V.S.; Murata, R.M.; Stebe, K.J.; Lee, D.; Koo, H. Candida albicans stimulates Streptococcus mutans microcolony development via cross-kingdom biofilm-derived metabolites. Sci Rep. 2017, 7, 41332. [CrossRef] [PubMed]

52. Koo, H.; Hayacibara, M.F.; Schobel, B.D.; Cury, J.A.; Rosalen, P.L.; Park, Y.K.; Vacca-Smith, A.M.; Bowen, W.H. Inhibition of Streptococcus mutans biofilm accumulation and polysaccharide production by apigenin and tt-farnesol. J. Antimicrob. Chemother. 2003, 52, 782-789. [CrossRef] [PubMed]

53. Russell, M.W.; Bergmeier, L.A.; Zanders, E.D.; Lehner, T. Protein antigens of Streptococcus mutans: Purification and properties of a double antigen and its protease-resistant component. Infect. Immun. 1980, 28, 486-493. [PubMed] 
54. Yang, C.; Scoffield, J.; Wu, R.; Deivanayagam, C.; Zou, J.; Wu, H. Antigen I/II mediates interactions between Streptococcus mutans and Candida albicans. Mol. Oral Microbiol. 2018, 33, 283-291. [CrossRef] [PubMed]

55. Zheng, W.; Tan, T.K.; Paterson, I.C.; Mutha, N.V.; Siow, C.C.; Tan, S.Y.; Old, L.A.; Jakubovics, N.S.; Choo, S.W. Streptobase: An oral Streptococcus mitis group genomic resource and analysis platform. PLoS ONE 2016, 11. [CrossRef] [PubMed]

56. Jenkinson, H.F.; Lala, H.C.; Shepherd, M.G. Coaggregation of Streptococcus sanguis and other streptococci with Candida albicans. Infect. Immun. 1990, 58, 1429-1436. [PubMed]

57. Diaz, P.I.; Chalmers, N.I.; Rickard, A.H.; Kong, C.; Milburn, C.L.; Palmer, R.J., Jr.; Kolenbrander, P.E. Molecular characterization of subject-specific oral microflora during initial colonization of enamel. Appl. Environ. Microbiol. 2006, 72, 2837-2848. [CrossRef] [PubMed]

58. Bamford, C.V.; d'Mello, A.; Nobbs, A.H.; Dutton, L.C.; Vickerman, M.M.; Jenkinson, H.F. Streptococcus gordonii modulates Candida albicans biofilm formation through intergeneric communication. Infect. Immun. 2009, 77, 3696-3704. [CrossRef] [PubMed]

59. Montelongo-Jauregui, D.; Srinivasan, A.; Ramasubramanian, A.K.; Lopez-Ribot, J.L. An in vitro model for oral mixed biofilms of Candida albicans and Streptococcus gordonii in synthetic saliva. Front. Microbiol 2016, 7 , 686. [CrossRef] [PubMed]

60. Montelongo-Jauregui, D.; Srinivasan, A.; Ramasubramanian, A.K.; Lopez-Ribot, J.L. An in vitro model for Candida albicans (-)Streptococcus gordonii biofilms on titanium surfaces. J. Fungi 2018, 4, 66. [CrossRef] [PubMed]

61. Nobbs, A.H.; Vickerman, M.M.; Jenkinson, H.F. Heterologous expression of Candida albicans cell wall-associated adhesins in Saccharomyces cerevisiae reveals differential specificities in adherence and biofilm formation and in binding oral Streptococcus gordonii. Eukaryot. Cell 2010, 9, 1622-1634. [CrossRef] [PubMed]

62. Holmes, A.R.; McNab, R.; Jenkinson, H.F. Candida albicans binding to the oral bacterium Streptococcus gordonii involves multiple adhesin-receptor interactions. Infect. Immun. 1996, 64, 4680-4685. [PubMed]

63. Dutton, L.C.; Nobbs, A.H.; Jepson, K.; Jepson, M.A.; Vickerman, M.M.; Aqeel Alawfi, S.; Munro, C.A.; Lamont, R.J.; Jenkinson, H.F. O-mannosylation in Candida albicans enables development of interkingdom biofilm communities. MBio 2014, 5. [CrossRef] [PubMed]

64. Dutton, L.C.; Jenkinson, H.F.; Lamont, R.J.; Nobbs, A.H. Role of Candida albicans secreted aspartyl protease sap9 in interkingdom biofilm formation. Pathog. Dis. 2016, 74. [CrossRef] [PubMed]

65. Rickard, A.H.; Palmer, R.J., Jr.; Blehert, D.S.; Campagna, S.R.; Semmelhack, M.F.; Egland, P.G.; Bassler, B.L.; Kolenbrander, P.E. Autoinducer 2: A concentration-dependent signal for mutualistic bacterial biofilm growth. Mol. Microbiol. 2006, 60, 1446-1456. [CrossRef] [PubMed]

66. Federle, M.J. Autoinducer-2-based chemical communication in bacteria: Complexities of interspecies signaling. Contrib. Microbiol. 2009, 16, 18-32. [PubMed]

67. Ricker, A.; Vickerman, M.; Dongari-Bagtzoglou, A. Streptococcus gordonii glucosyltransferase promotes biofilm interactions with Candida albicans. J. Oral Microbiol. 2014, 6. [CrossRef] [PubMed]

68. Koo, H.; Xiao, J.; Klein, M.I.; Jeon, J.G. Exopolysaccharides produced by Streptococcus mutans glucosyltransferases modulate the establishment of microcolonies within multispecies biofilms. J. Bacteriol. 2010, 192, 3024-3032. [CrossRef] [PubMed]

69. Jack, A.A.; Daniels, D.E.; Jepson, M.A.; Vickerman, M.M.; Lamont, R.J.; Jenkinson, H.F.; Nobbs, A.H. Streptococcus gordonii comcde (competence) operon modulates biofilm formation with Candida albicans. Microbiology 2015, 161, 411-421. [CrossRef] [PubMed]

70. Xu, H.; Sobue, T.; Bertolini, M.; Thompson, A.; Vickerman, M.; Nobile, C.J.; Dongari-Bagtzoglou, A.S. Oralis activates the EFG1 filamentation pathway in C. albicans to promote cross-kingdom interactions and mucosal biofilms. Virulence 2017, 8, 1602-1617. [CrossRef] [PubMed]

71. Bertolini, M.; Sobue, T.; Thompson, A.; Dongari-Bagtzoglou, A. Chemotherapy induces oral mucositis in mice without additional noxious stimuli. Transl. Oncol. 2017, 10, 612-620. [CrossRef] [PubMed]

72. Sobue, T.; Bertolini, M.; Thompson, A.; Peterson, D.E.; Diaz, P.I.; Dongari-Bagtzoglou, A. Chemotherapy-induced oral mucositis and associated infections in a novel organotypic model. Mol. Oral Microbiol. 2018, 33, 212-223. [CrossRef] [PubMed]

73. Bagg, J.; Silverwood, R.W. Coagglutination reactions between Candida albicans and oral bacteria. J. Med. Microbiol. 1986, 22, 165-169. [CrossRef] [PubMed] 
74. Xu, H.; Sobue, T.; Thompson, A.; Xie, Z.; Poon, K.; Ricker, A.; Cervantes, J.; Diaz, P.I.; Dongari-Bagtzoglou, A. Streptococcal co-infection augments candida pathogenicity by amplifying the mucosal inflammatory response. Cell. Microbiol. 2014, 16, 214-231. [CrossRef] [PubMed]

75. Bertolini, M.M.; Xu, H.; Sobue, T.; Nobile, C.J.; Del Bel Cury, A.A.; Dongari-Bagtzoglou, A. Candida-streptococcal mucosal biofilms display distinct structural and virulence characteristics depending on growth conditions and hyphal morphotypes. Mol. Oral Microbiol. 2015, 30, 307-322. [CrossRef] [PubMed]

76. Xu, H.; Sobue, T.; Bertolini, M.; Thompson, A.; Dongari-Bagtzoglou, A. Streptococcus oralis and Candida albicans synergistically activate mu-calpain to degrade E-cadherin from oral epithelial junctions. J. Infect. Dis. 2016, 214, 925-934. [CrossRef] [PubMed]

77. Ma, S.; Li, H.; Yan, C.; Wang, D.; Li, H.; Xia, X.; Dong, X.; Zhao, Y.; Sun, T.; Hu, P.; et al. Antagonistic effect of protein extracts from Streptococcus sanguinis on pathogenic bacteria and fungi of the oral cavity. Exp. Ther. Med. 2014, 7, 1486-1494. [CrossRef] [PubMed]

78. Cavalcanti, Y.W.; Morse, D.J.; da Silva, W.J.; Del-Bel-Cury, A.A.; Wei, X.; Wilson, M.; Milward, P.; Lewis, M.; Bradshaw, D.; Williams, D.W. Virulence and pathogenicity of Candida albicans is enhanced in biofilms containing oral bacteria. Biofouling 2015, 31, 27-38. [CrossRef] [PubMed]

79. Cavalcanti, Y.W.; Wilson, M.; Lewis, M.; Del-Bel-Cury, A.A.; da Silva, W.J.; Williams, D.W. Modulation of Candida albicans virulence by bacterial biofilms on titanium surfaces. Biofouling 2016, 32, 123-134. [CrossRef] [PubMed]

80. Fujimura, S.; Nakamura, T. Sanguicin, a bacteriocin of oral Streptococcus sanguis. Antimicrob. Agents Chemother. 1979, 16, 262-265. [CrossRef] [PubMed]

81. Palma, A.; Ramos, L.P.; Domingues, N.; Back-Brito, G.N.; de Oliveira, L.D.; Pereira, C.A.; Jorge, A.O.C. Biofilms of Candida albicans and Streptococcus sanguinis and their susceptibility to antimicrobial effects of photodynamic inactivation. Photodiagn. Photodyn. Ther. 2018. [CrossRef] [PubMed]

82. Ishijima, S.A.; Hayama, K.; Burton, J.P.; Reid, G.; Okada, M.; Matsushita, Y.; Abe, S. Effect of Streptococcus salivarius $\mathrm{K} 12$ on the in vitro growth of Candida albicans and its protective effect in an oral candidiasis model. Appl. Environ. Microbiol. 2012, 78, 2190-2199. [CrossRef] [PubMed]

83. How, K.Y.; Song, K.P.; Chan, K.G. Porphyromonas gingivalis: An overview of periodontopathic pathogen below the gum line. Front. Microbiol. 2016, 7, 53. [CrossRef] [PubMed]

84. Sztukowska, M.N.; Dutton, L.C.; Delaney, C.; Ramsdale, M.; Ramage, G.; Jenkinson, H.F.; Nobbs, A.H.; Lamont, R.J. Community development between Porphyromonas gingivalis and Candida albicans mediated by inlj and als3. MBio 2018, 9. [CrossRef] [PubMed]

85. Tamai, R.; Sugamata, M.; Kiyoura, Y. Candida albicans enhances invasion of human gingival epithelial cells and gingival fibroblasts by Porphyromonas gingivalis. Microb. Pathog. 2011, 51, 250-254. [CrossRef] [PubMed]

86. Wright, C.J.; Burns, L.H.; Jack, A.A.; Back, C.R.; Dutton, L.C.; Nobbs, A.H.; Lamont, R.J.; Jenkinson, H.F. Microbial interactions in building of communities. Mol. Oral Microbiol. 2013, 28, 83-101. [CrossRef] [PubMed]

87. Daep, C.A.; Novak, E.A.; Lamont, R.J.; Demuth, D.R. Structural dissection and in vivo effectiveness of a peptide inhibitor of Porphyromonas gingivalis adherence to Streptococcus gordonii. Infect. Immun. 2011, 79, 67-74. [CrossRef] [PubMed]

88. Hajishengallis, G.; Lamont, R.J. Dancing with the stars: How choreographed bacterial interactions dictate nososymbiocity and give rise to keystone pathogens, accessory pathogens, and pathobionts. Trends Microbiol. 2016, 24, 477-489. [CrossRef] [PubMed]

89. Haverman, T.M.; Laheij, A.; de Soet, J.J.; de Lange, J.; Rozema, F.R. Candida and Porphyromonas gingivalis: The effect on wound closure in vitro. J. Oral Microbiol. 2017, 9, 1328266. [CrossRef] [PubMed]

90. Al-Ahmad, A.; Follo, M.; Selzer, A.C.; Hellwig, E.; Hannig, M.; Hannig, C. Bacterial colonization of enamel in situ investigated using fluorescence in situ hybridization. J. Med. Microbiol. 2009, 58, 1359-1366. [CrossRef] [PubMed]

91. Palmer, R.J., Jr.; Kazmerzak, K.; Hansen, M.C.; Kolenbrander, P.E. Mutualism versus independence: Strategies of mixed-species oral biofilms in vitro using saliva as the sole nutrient source. Infect. Immun. 2001, 69, 5794-5804. [CrossRef] [PubMed]

92. Palmer, R.J., Jr.; Gordon, S.M.; Cisar, J.O.; Kolenbrander, P.E. Coaggregation-mediated interactions of Streptococci and Actinomyces detected in initial human dental plaque. J. Bacteriol. 2003, 185, 3400-3409. [CrossRef] [PubMed] 
93. Gutierrez de Annan, S.; Benito de Cardenas, L. Effect of metabolic substances of oral Actinomyces on Candida albicans. Rev. Iberoam. Micol. 2004, 21, 29-34. [PubMed]

94. Grimaudo, N.J.; Nesbitt, W.E.; Clark, W.B. Coaggregation of Candida albicans with oral actinomyces species. Oral Microbiol. Immunol. 1996, 11, 59-61. [CrossRef] [PubMed]

95. Arzmi, M.H.; Dashper, S.; Catmull, D.; Cirillo, N.; Reynolds, E.C.; McCullough, M. Coaggregation of Candida albicans, Actinomyces naeslundii and Streptococcus mutans is Candida albicans strain dependent. FEMS Yeast Res. 2015, 15, fov038. [CrossRef] [PubMed]

96. Arzmi, M.H.; Alnuaimi, A.D.; Dashper, S.; Cirillo, N.; Reynolds, E.C.; McCullough, M. Polymicrobial biofilm formation by Candida albicans, Actinomyces naeslundii, and Streptococcus mutans is Candida albicans strain and medium dependent. Med. Mycol. 2016, 54, 856-864. [CrossRef] [PubMed]

97. Cavalcanti, I.M.; Nobbs, A.H.; Ricomini-Filho, A.P.; Jenkinson, H.F.; Del Bel Cury, A.A. Interkingdom cooperation between Candida albicans, Streptococcus oralis and Actinomyces oris modulates early biofilm development on denture material. Pathog. Dis. 2016, 74. [CrossRef]

98. Cavalcanti, I.M.; Del Bel Cury, A.A.; Jenkinson, H.F.; Nobbs, A.H. Interactions between Streptococcus oralis, Actinomyces oris, and Candida albicans in the development of multispecies oral microbial biofilms on salivary pellicle. Mol. Oral Microbiol. 2017, 32, 60-73. [CrossRef] [PubMed]

99. Guo, Y.; Wei, C.; Liu, C.; Li, D.; Sun, J.; Huang, H.; Zhou, H. Inhibitory effects of oral Actinomyces on the proliferation, virulence and biofilm formation of Candida albicans. Arch. Oral Biol. 2015, 60, 1368-1374. [CrossRef] [PubMed]

100. Han, Y.W. Fusobacterium nucleatum: A commensal-turned pathogen. Curr. Opin. Microbiol. 2015, 23, $141-147$. [CrossRef] [PubMed]

101. Grimaudo, N.J.; Nesbitt, W.E. Coaggregation of Candida albicans with oral Fusobacterium species. Oral Microbiol. Immunol. 1997, 12, 168-173. [CrossRef] [PubMed]

102. Jabra-Rizk, M.A.; Falkler, W.A., Jr.; Merz, W.G.; Kelley, J.I.; Baqui, A.A.; Meiller, T.F. Coaggregation of Candida dubliniensis with Fusobacterium nucleatum. J. Clin. Microbiol. 1999, 37, 1464-1468. [PubMed]

103. Wu, T.; Cen, L.; Kaplan, C.; Zhou, X.; Lux, R.; Shi, W.; He, X. Cellular components mediating coadherence of Candida albicans and Fusobacterium nucleatum. J. Dent. Res. 2015, 94, 1432-1438. [CrossRef] [PubMed]

104. Kaplan, C.W.; Lux, R.; Haake, S.K.; Shi, W. The Fusobacterium nucleatum outer membrane protein RADD is an arginine-inhibitable adhesin required for inter-species adherence and the structured architecture of multispecies biofilm. Mol. Microbiol. 2009, 71, 35-47. [CrossRef] [PubMed]

105. Kaplan, A.; Kaplan, C.W.; He, X.; McHardy, I.; Shi, W.; Lux, R. Characterization of aid1, a novel gene involved in Fusobacterium nucleatum interspecies interactions. Microb. Ecol. 2014, 68, 379-387. [CrossRef] [PubMed]

106. Bor, B.; Cen, L.; Agnello, M.; Shi, W.; He, X. Morphological and physiological changes induced by contact-dependent interaction between Candida albicans and Fusobacterium nucleatum. Sci. Rep. 2016, 6, 27956. [CrossRef] [PubMed]

107. Elving, G.J.; van Der Mei, H.C.; Busscher, H.J.; van Weissenbruch, R.; Albers, F.W. Air-flow resistances of silicone rubber voice prostheses after formation of bacterial and fungal biofilms. J. Biomed. Mater. Res. 2001, 58, 421-426. [CrossRef] [PubMed]

108. van der Mei, H.C.; Buijssen, K.J.; van der Laan, B.F.; Ovchinnikova, E.; Geertsema-Doornbusch, G.I.; Atema-Smit, J.; van de Belt-Gritter, B.; Busscher, H.J. Voice prosthetic biofilm formation and Candida morphogenic conversions in absence and presence of different bacterial strains and species on silicone-rubber. PLOS ONE 2014, 9. [CrossRef] [PubMed]

109. Millsap, K.W.; Bos, R.; van der Mei, H.C.; Busscher, H.J. Adhesive interactions between voice prosthetic yeast and bacteria on silicone rubber in the absence and presence of saliva. Antonie Van Leeuwenhoek 2001, 79, 337-343. [CrossRef] [PubMed]

110. Elving, G.J.; van der Mei, H.; Busscher, H.; van Weissenbruch, R.; Albers, F. Influence of different combinations of bacteria and yeasts in voice prosthesis biofilms on air flow resistance. Antonie Van Leeuwenhoek 2003, 83, 45-55. [CrossRef] [PubMed]

111. Uppuluri, P.; Busscher, H.J.; Chakladar, J.; van der Mei, H.C.; Chaffin, W.L. Transcriptional profiling of $C$. albicans in a two species biofilm with Rothia dentocariosa. Front. Cell. Infect. Microbiol. 2017, 7, 311. [CrossRef] [PubMed]

112. Raja, M.; Ummer, F.; Dhivakar, C.P. Aggregatibacter actinomycetemcomitans-A tooth killer? J. Clin. Diagn. Res. 2014, 8, ZE13-ZE16. [CrossRef] [PubMed] 
113. Bachtiar, E.W.; Bachtiar, B.M.; Jarosz, L.M.; Amir, L.R.; Sunarto, H.; Ganin, H.; Meijler, M.M.; Krom, B.P. Ai-2 of Aggregatibacter actinomycetemcomitans inhibits Candida albicans biofilm formation. Front. Cell. Infect. Microbiol. 2014, 4, 94. [CrossRef] [PubMed]

114. Shao, H.; Lamont, R.J.; Demuth, D.R. Autoinducer 2 is required for biofilm growth of aggregatibacter (actinobacillus) actinomycetemcomitans. Infect. Immun. 2007, 75, 4211-4218. [CrossRef] [PubMed]

115. McCormack, M.G.; Smith, A.J.; Akram, A.N.; Jackson, M.; Robertson, D.; Edwards, G. Staphylococcus aureus and the oral cavity: An overlooked source of carriage and infection? Am. J. Infect. Control 2015, 43, 35-37. [CrossRef] [PubMed]

116. Ohara-Nemoto, Y.; Haraga, H.; Kimura, S.; Nemoto, T.K. Occurrence of staphylococci in the oral cavities of healthy adults and nasal oral trafficking of the bacteria. J. Med. Microbiol. 2008, 57, 95-99. [CrossRef] [PubMed]

117. Baena-Monroy, T.; Moreno-Maldonado, V.; Franco-Martinez, F.; Aldape-Barrios, B.; Quindos, G.; Sanchez-Vargas, L.O. Candida albicans, Staphylococcus aureus and Streptococcus mutans colonization in patients wearing dental prosthesis. Med. Oral Patol. Oral Cir. Bucal. 2005, 10, E27-E39. [PubMed]

118. Samaranayake, L.P.; Cheung, L.K.; Samaranayake, Y.H. Candidiasis and other fungal diseases of the mouth. Dermatol. Ther. 2002, 15, 251-269. [CrossRef]

119. MacFarlane, T.W.; Helnarska, S.J. The microbiology of angular cheilitis. Br. Dent. J. 1976, 140, 403-406. [CrossRef] [PubMed]

120. Oza, N.; Doshi, J.J. Angular cheilitis: A clinical and microbial study. Indian J. Dent. Res. 2017, 28, 661-665. [CrossRef] [PubMed]

121. Terai, H.; Shimahara, M. Cheilitis as a variation of Candida-associated lesions. Oral Dis. 2006, 12, 349-352. [CrossRef] [PubMed]

122. Byadarahally Raju, S.; Rajappa, S. Isolation and identification of candida from the oral cavity. ISRN Dent. 2011, 2011, 487921. [CrossRef] [PubMed]

123. Peters, B.M.; Ovchinnikova, E.S.; Krom, B.P.; Schlecht, L.M.; Zhou, H.; Hoyer, L.L.; Busscher, H.J.; van der Mei, H.C.; Jabra-Rizk, M.A.; Shirtliff, M.E. Staphylococcus aureus adherence to Candida albicans hyphae is mediated by the hyphal adhesin Als3p. Microbiology 2012, 158, 2975-2986. [CrossRef] [PubMed]

124. Schlecht, L.M.; Peters, B.M.; Krom, B.P.; Freiberg, J.A.; Hansch, G.M.; Filler, S.G.; Jabra-Rizk, M.A.; Shirtliff, M.E. Systemic Staphylococcus aureus infection mediated by Candida albicans hyphal invasion of mucosal tissue. Microbiology 2015, 161, 168-181. [CrossRef] [PubMed]

125. Kean, R.; Rajendran, R.; Haggarty, J.; Townsend, E.M.; Short, B.; Burgess, K.E.; Lang, S.; Millington, O.; Mackay, W.G.; Williams, C.; et al. Candida albicans mycofilms support Staphylococcus aureus colonization and enhances miconazole resistance in dual-species interactions. Front. Microbiol. 2017, 8, 258. [CrossRef] [PubMed]

126. Kong, E.F.; Tsui, C.; Kucharikova, S.; Andes, D.; Van Dijck, P.; Jabra-Rizk, M.A. Commensal protection of Staphylococcus aureus against antimicrobials by Candida albicans biofilm matrix. MBio 2016, 7. [CrossRef] [PubMed]

127. Hermann, C.; Hermann, J.; Munzel, U.; Ruchel, R. Bacterial flora accompanying Candida yeasts in clinical specimens. Mycoses 1999, 42, 619-627. [CrossRef] [PubMed]

128. Kovac, J.; Kovac, D.; Slobodnikova, L.; Kotulova, D. Enterococcus faecalis and Candida albicans in the dental root canal and periapical infections. Bratisl. Lek. Listy 2013, 114, 716-720. [PubMed]

129. Dahlen, G.; Blomqvist, S.; Almstahl, A.; Carlen, A. Virulence factors and antibiotic susceptibility in Enterococci isolated from oral mucosal and deep infections. J. Oral Microbiol. 2012, 4. [CrossRef] [PubMed]

130. Cruz, M.R.; Graham, C.E.; Gagliano, B.C.; Lorenz, M.C.; Garsin, D.A. Enterococcus faecalis inhibits hyphal morphogenesis and virulence of Candida albicans. Infect. Immun. 2013, 81, 189-200. [CrossRef] [PubMed]

131. Graham, C.E.; Cruz, M.R.; Garsin, D.A.; Lorenz, M.C. Enterococcus faecalis bacteriocin entv inhibits hyphal morphogenesis, biofilm formation, and virulence of Candida albicans. Proc. Natl. Acad. Sci. USA 2017, 114, 4507-4512. [CrossRef] [PubMed]

132. Coronado-Castellote, L.; Jimenez-Soriano, Y. Clinical and microbiological diagnosis of oral candidiasis. J. Clin. Exp. Dent. 2013, 5, e279-e286. [CrossRef] [PubMed]

133. Urzua, B.; Hermosilla, G.; Gamonal, J.; Morales-Bozo, I.; Canals, M.; Barahona, S.; Coccola, C.; Cifuentes, V. Yeast diversity in the oral microbiota of subjects with periodontitis: Candida albicans and Candida dubliniensis colonize the periodontal pockets. Med. Mycol. 2008, 46, 783-793. [CrossRef] [PubMed] 
134. Rossoni, R.D.; Barbosa, J.O.; Vilela, S.F.; dos Santos, J.D.; de Barros, P.P.; Prata, M.C.; Anbinder, A.L.; Fuchs, B.B.; Jorge, A.O.; Mylonakis, E.; et al. Competitive interactions between C. albicans, C. glabrata and C. krusei during biofilm formation and development of experimental candidiasis. PLOS ONE 2015, 10. [CrossRef] [PubMed]

135. Barros, P.P.; Ribeiro, F.C.; Rossoni, R.D.; Junqueira, J.C.; Jorge, A.O. Influence of Candida krusei and Candida glabrata on Candida albicans gene expression in in vitro biofilms. Arch. Oral Biol. 2016, 64, 92-101. [CrossRef] [PubMed]

136. Santos, J.D.; Piva, E.; Vilela, S.F.; Jorge, A.O.; Junqueira, J.C. Mixed biofilms formed by C. albicans and non-albicans species: A study of microbial interactions. Braz. Oral Res. 2016, 30. [CrossRef] [PubMed]

137. Rossoni, R.D.; Barros, P.P.; Freire, F.; Santos, J.D.D.; Jorge, A.O.C.; Junqueira, J.C. Study of microbial interaction formed by "Candida krusei" and "Candida glabrata": "In vitro" and "in vivo" studies. Braz. Dent. J. 2017, 28, 669-674. [CrossRef] [PubMed]

138. Coco, B.J.; Bagg, J.; Cross, L.J.; Jose, A.; Cross, J.; Ramage, G. Mixed Candida albicans and Candida glabrata populations associated with the pathogenesis of denture stomatitis. Oral Microbiol. Immunol. 2008, 23, 377-383. [CrossRef] [PubMed]

139. Vipulanandan, G.; Herrera, M.; Wiederhold, N.P.; Li, X.; Mintz, J.; Wickes, B.L.; Kadosh, D. Dynamics of mixed-Candida species biofilms in response to antifungals. J. Dent. Res. 2018, 97, 91-98. [CrossRef] [PubMed]

140. Hsu, L.Y.; Minah, G.E.; Peterson, D.E.; Wingard, J.R.; Merz, W.G.; Altomonte, V.; Tylenda, C.A. Coaggregation of oral Candida isolates with bacteria from bone marrow transplant recipients. J. Clin. Microbiol. 1990, 28, 2621-2626. [PubMed]

(C) 2018 by the authors. Licensee MDPI, Basel, Switzerland. This article is an open access article distributed under the terms and conditions of the Creative Commons Attribution (CC BY) license (http:/ / creativecommons.org/licenses/by/4.0/). 